\title{
MODIFICATION OF THEORY OF PLANNED BEHAVIOR TO MEASURE THE INTENTIONS AND BEHAVIOR OF PEOPLES PARTICIPATION IN THE WASTE BANK PROGRAM (CASE: BANTUL REGENCY)
}

\author{
Anggun Nindy Fatliana ${ }^{1 *}$, Naniek Utami Handayani ${ }^{1 *}$, Manik Mahacandra ${ }^{1 *}$, \\ Utaminingsih Linarti ${ }^{2 *}$ \\ ${ }^{1}$ Department of Industrial Engineering and Management, Diponegoro University \\ ${ }^{2}$ Department of Industrial Engineering, Ahmad Dahlan University
}

\begin{abstract}
Waste is an environmental problem that hasn't been resolved until now. This problem can be overcome with the waste bank program. The success of the waste bank is supported by the high level of community participation. Currently, the level of community participation in Bantul Regency is still low, which is below 50\%. The purpose of this research is to investigates what factors that can increase people's intention and behavior of participating in waste bank activities at Bantul Regency. This research using factors from Theory of Planned Behavior (TPB) model. Besides of factors from Theory of Planned Behavior this research added other factors like knowledge of how and what, knowledge of the consequences and situational factors used as a measurement tools. The research used 300 samples. The target respondents for this research are members who actively participate in the waste bank activities. The sampling technique is purposive sampling, regression analysis methods is using on this research. The analysis results showed that attitudes, subjective norms, knowledge of how and what, knowledge of consequence and situational factor have a significant effect on the people's intention to participate in the waste bank programs. Meanwhile the perceived control behavior variable has no significant effect on the people's intention to participate in the waste bank program. All the factors togethers can explain the intention of $44.7 \%$.
\end{abstract}

Keywords: waste bank activities; TPB model; knowledge of how and what; knowledge of consequence; situational factors.

\section{Introduction}

One of the problems caused by the increasing population of Indonesia is the problem of the waste. A lot of bad achievement that have been get by Indonesia always about the waste. According to the data from the International Earth Science Information Network in 2012, Indonesia is included in the top 10 dirtiest countries in the world. Moreover, based on the research from the Ministry of Environment and Forestry in 2016, Indonesia is the 2nd largest producer of plastic waste in the sea. From these data it is enough to illustrate that Indonesia has not been able to manage waste properly. Based on UU number 18 in 2018 about Waste Management, everyone has a responsibility to reduce and handle waste in the environment. But the fact, based on BPS data, around 72 percent of Indonesian people don't care about the waste, as happened in the case of a dead whale in

*Penulis Korespondensi.

E-Mail: anggunnindyfatliana@students.undip.ac.id, naniekh@live.undip.ac.id, manik.mahachandra@gmail.com, utaminingsih.linarti@ie.uad.ac.id
Wakatobi, $40 \mathrm{~kg}$ of plastic waste was found in the whale's stomach. If this condition continues, the natural ecosystem will be disturbed and can be destroy various kinds of living things. Another problem is that there are so many people who burn plastic waste, burning plastic waste is an act that is harmful to health and the environment. Burning plastic waste will produce carbon monoxide ( $\mathrm{CO}$ ) and if inhaled by humans will give an effect to the work function of red blood cells, all this time there is nothing activities of waste sorting. So far, unsorted waste will only be piled up into a mountain of garbage in the landfill (TPA) and in the end it will only become an environmental problem. Data from the Ministry of Environment and Forestry in 2017 said that 60 percent of the 64 million tons of waste in Indonesia is organic waste. It can be imagined if everyone managed their own waste, there would be 38.4 million tons of organic waste that was used as fertilizer and could reduce the mountain of garbage in the landfill (TPA). As in the case in 2019, the Piyungan TPA, Bantul, Yogyakarta had stopped operating for 5 days because the waste entering the Piyungan TPA had exceeded the capacity.

Bantul Regency is the second district with the highest population in the city of Yogyakarta and 
continues to increase every year. Based on BPS data in 2012, the population of Bantul Regency was 927,958 people, increasing to 995,365 people in 2017. In 2017 the DLH Bantul Regency said that the volume of waste entering the Piyungan TPAS reached 60 tons every day. Bantul Regency has a lot of volume of waste, total waste pile in 2013 was $32,544.67 \mathrm{~m}^{3} /$ day, this increased compared to 2012 which amounted to $2,283.28 \mathrm{~m}^{3} /$ day. This problem can be solved by recycling waste. In Indonesia, recycling activities are carried out by implementing the 3R (Reduce, Reuse, and Recycle) suitable with the Minister of Environment Regulation Number 13 in 2012. However, this activity is still having a lot of obstacles, like the level of public awareness is less about sorting waste (Prihatmoko, 2018). The solution to overcome the less of public awareness to sort waste is through the development of a waste bank program. The waste bank is a waste management program by utilizing the waste selection. So, any time you can take the advantage of it such as money that you get from the waste bank program.

Based on data from the Center for the Environment (BLH) of the Special Region of Yogyakarta in 2015, Bantul Regency was recorded to have 46 waste banks spread across sub-districts in Bantul Regency. But based on the results of observations (Khurniawan et al, 2017) not all waste banks are registered as active waste banks, there are also some inactive waste banks there, only 24 active waste banks located in the Bantul Regency area. The data illustrates that the level of community participation in waste banks is very less, this is influenced by several factors such as socialization and training from the government regarding the waste bank program that is not evenly distributed (Prihatmoko, 2018), people do not understand the knowledge of how and what kind of waste to be disposed of sorted out as well as knowledge about the consequences with the existence of a waste bank. People prefer to deposit directly into the waste bank instead of sorting it out at their home. It is because people tend to feel lazy in processing waste due to less of knowledge (Mulasari, et al, 2014). Availability facilities and infrastructure such as the availability of buildings from waste banks, trash bins and the other facilities that are lacking also make the people's not to participate in the waste bank program (Boldero, 1995); (Tonglet, 2004).

Understanding people's behavior in waste management can use psychological theory concern to the relationship between attitudes and behavior. The Theory of Planned Behavior (TPB) which has been developed to be applied to explain intention which is the closest antecedent of behavior. A person's intention is a determinant of whether someone will do certain behaviors (Ajzen, 1991). According to Ajzen (1991), a person's intention towards sustainable waste management behavior is measured through three determinants, namely attitudes, subjective norms, and perception control. Attitude is defined as a factor in a person who gives a positive or negative response to something given. Subjective norms are social pressures faced by individuals to do or not do something. Behavior control is the perception of easy or difficult of performing a behavior. Based on several studies Boldero, (1995); Gusti, (2015); Gadiraju, (2016); Ittiravivong, (2011); Ramayah, (2017); Tonglet,(2004); Davis, (2012); Sun, (2018); Pratiwi, (2018); Prihatmoko, (2018); Taqwarahman, (2018); concerning to the behavior of waste recycling, it was found that the TPB model was used as an instrument to measure a person's intentions and behavior. The results showed that the determinants of Theory planned of behavior (TPB) were significantly able to explain the behavior of waste recycling.

Ajzen, (1991) argues that the TPB model is less accurate in explaining a person's behavior, so it is possible to incorporate additional variables if these variables can make a significant contribution to the explanation of behavior. This statement is strengthened by (Gadiraju, 2016) which said that although there is sufficient support for the use of TPB, there are concerns that this does not adequately explain recycling behavior so that additional variables must be included in the model (Boldero, 1995; Cheung et al 1999; Davis et al. , 2004; Tonglet, 2004). Ittiravivong Research, (2017); Davis et al, (2004); Latif et al, (2012); Boldero, (1995); Sun, (2018); Pratiwi, (2018) adds a situational factor as an independent factor in TPB to measure the intention of community participation in waste recycling, the results show that situational factors have a significant influence on recycling behavior. It means that the fewer facilities available, the lower participation in recycling will be.

In addition to situational factors in Gadiraju's research, (2016) added knowledge factors of what why, and knowledge of consequences on the TPB model to see the intentions and behavior of participation in recycling students at the University of South Florida. The results showed that the factor of knowledge of how and what, and knowledge of the consequence significantly affect the intention and behavior of student participation in recycling. Riadi, (2001) shows that there is a significant relationship of the level of knowledge and people's participation in the waste bank program. The addition of the variable knowledge of how and what, knowledge of the consequences has been done to determine the intentions and behavior of the community in participating in the waste bank. The result is that these two factors are significant in influencing a person's intention to participate in waste bank activities (Prihatmoko, 2018); (Taqwarahman, 2018).

\section{Objectives}

The purpose of this research is to determine which factors influence the intention and how much intention influences the people's participation behavior in participating of the waste bank program.

\section{Literature Review}

According to Ajzen (1975) in Theory of Planned Behavior (TPB), there are three determinant that can measure Intention. These components are attitude, 


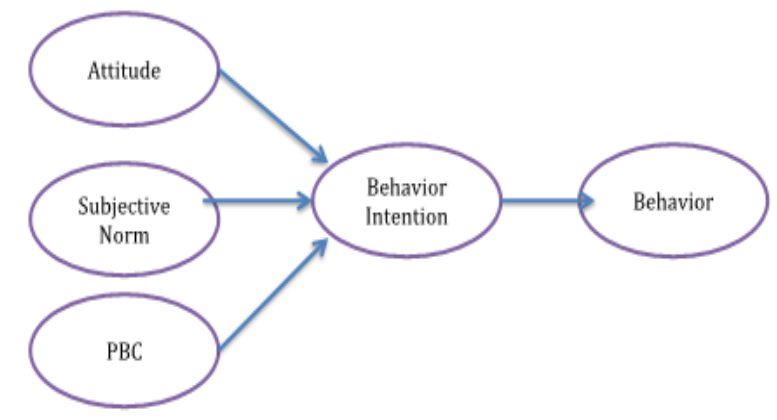

Figure 1. Theory Of Planned Behavior: Ajzen (1991)

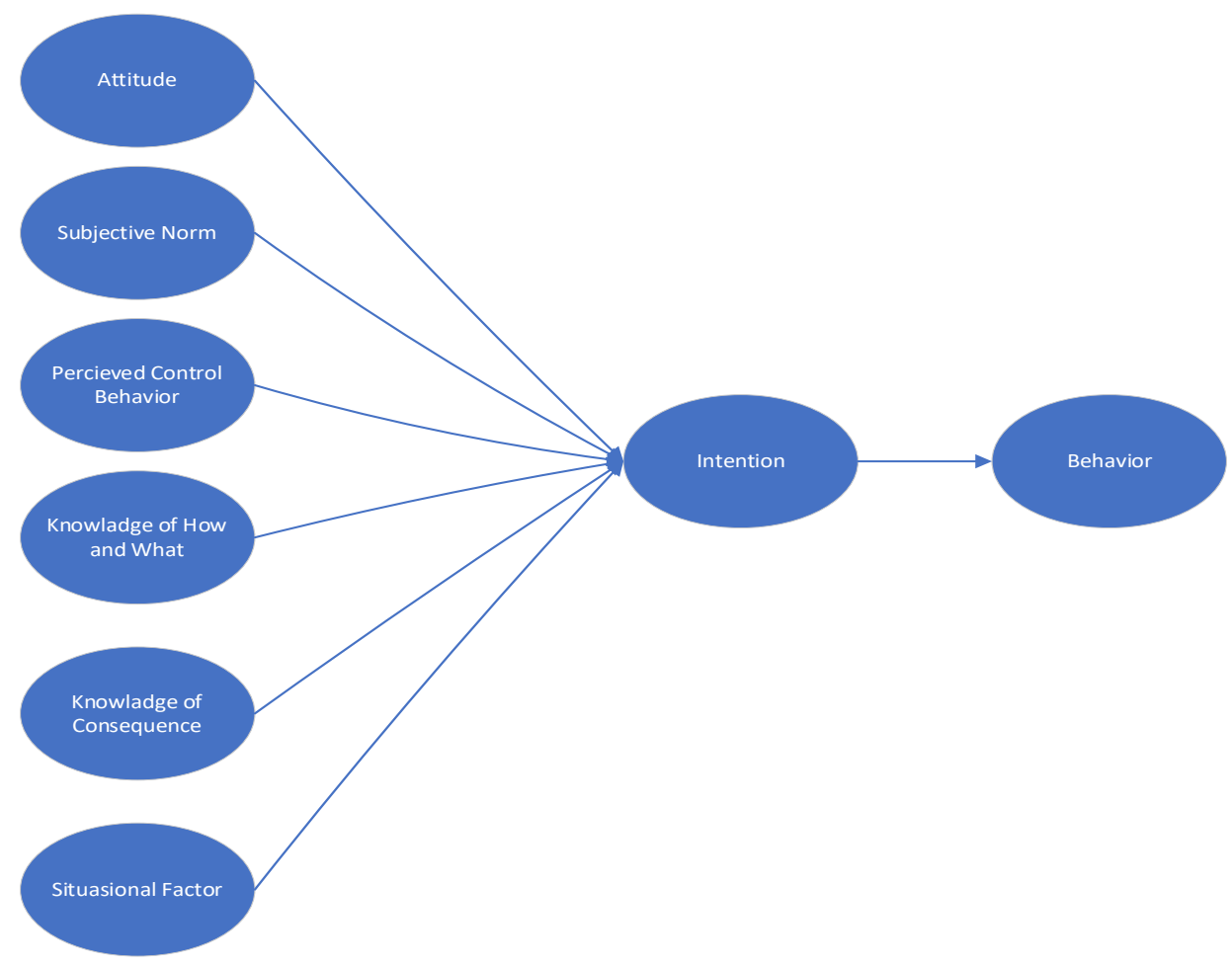

Figure 2. Conceptual Model

subjective norm, and perceived control behavior. The TPB theory was developed from the previous Theory of Reasoned Action (TRA). The Theory of Reasoned Action (TRA) was coined by (Fishbein and Ajzen, 1975), this theory is structured by using the basic assumption that humans behave in a conscious way and consider all available information. In this theory, a person's behavior is determined by 2 factors, namely attitude toward the behavior and subjective norms. This theory was further developed by Ajzen (1985) into Theory of Planned Behavior (TPB) by including another variable, namely perception control into the model that shows the individual's ability to have control over behavior. The Theory of Planned Behavior (TPB) is intended to predict individual behavior more specifically (Ramdhani, 2011). The Theory of Planned Behavior (TPB) which has been developed is widely applied to explain intention which is the closest antecedent of behavior. A person's intention is a determinant of whether someone will do certain behaviors (Ajzen, 1991).

This research refers to the basic model (Ajzen, 1991), namely TPB which has a variable component of
Attitude, Subjective Norm, Perceived Control Behavior, Intention and Behavior as shown on Figure 1. Furthermore, the researchers made modifications by adding knowledge variables, namely knowledge of how and what (KOHW), knowledge of consequence (KOC), and situasional factor which refers to the research model of Davis (2002); Gadiraju (2016); Ramayah (2012); Prihatmoko (2018); Taqwarrahman (2018); Gadiraju (2016); Tonglet (2004); , situational factors referring to Ittiravivong's (2011) research model; Davis (2002); Boldero (1995); Latif (2012); Sun (2018); Pratiwi (2018).

Figure 2 is a conceptual model in this research.

\section{Methods}

The purpose of this research is to investigates what factors that can increase people's intention and behavior of participating in waste bank activities at Bantul Regency using a quantitative approach. Object of this research is member who actively participate in waste bank activities in Bantul Regency. There are 10 Waste Banks used in this research. The sampling technique used is purposive sampling. This research has independent 
variables there are 6 variables namely attitudes, subjective norms, perceived controls, knowledge of how and what, knowledge of consequence, and situational factors, meanwhile for the dependent variable there are 2 variables, namely intentions and behavior. The analytical method used in this research is regression analysis. Data collection using a closed questionnaire with a sample size of 300 samples. Before the questionnaires distributed to respondents, a face validity test was carried out first by two validators who expert with this topic to determine that the questionnaire was appropriate and worthy to be distributed to respondents. Then the questionnaire that has been distributed to the respondents will be tested for construct validity and reliability. Previously, the results of the respondent's data were examined for data, namely: (1) Identification of missing data and (2) outlier data (Hair et al, 2007).

\section{Data Collection}

Researchers conducted several ways of collecting data to meet the data needed in this research. The methods for collecting data are as follows:

\subsection{Questionnaire}

The researcher has prepared several questions in writing, the questions are in the form of matters relating to the problem to be studied and filling out the questionnaire is carried out by the respondent concerned. To see whether the questionnaire can be used as a measuring tool, it is necessary to carry out the following tests:

a. Face Validity

Face validity is used for testing the questionnaire before it is distributed to respondents.

b. Validity and Reliability

Determine how valid a question item measures the variable under research. Reliability test is a statistical test used to determine the reliability of a series of question items in measuring a variable's reliability.

The questionnaire assessment method uses a Likert scale, namely by weighting each question item on a scale of 1 to 5 from strongly disagree to strongly agree.

\subsection{Observation}

Researchers make direct observations to an object that is in the ongoing environment including various activities to obtain data related to existing problems.

\subsection{Interview}

The author goes into the place directly to get data related to the problem.

\subsection{Literature Study}

Researchers conduct literature studies by studying theories from various references such as prior research, research journals, books and information related to this research. How many questionnaires are distributed in each waste bank can be seen in Table 1.

\section{Results and Discussion}

\subsection{Results}

There are 4 stages of data processing in this study, namely reliability test, validity test, classical assumption test consisting of normality test, heteroscedasticity test and multicollinearity test. Then, the multiple regression analysis test or analysis of the results of the hypothesis is carried out. Based on the research model in Figure 2, the regression analysis test was not carried out simultaneously but partially. There are two stages carried out in this research, namely, (1) Measuring the respondent's intention in participating in the Waste Bank activities and (2) Measuring the respondent's behavior in participating in the Waste Bank activities.

\section{The First Stage}

The first step in this research is reliability test. The reliability test is used to measure a questionnaire which is an indicator of a variable (Ghozali, 2018). A questionnaire will be reliable if the Cronbach's alpha value is $>0.60$ and it will be unreliable if the Cronbach's alpha value is $<0.60$. In this test, all variables have a Cronbach's Alpha count $>0.60$ as you can see on Table $\mathbf{2}$, so it can be concluded that all the variables that used in this research model can be said to be reliable and feasible to be used as measuring instruments.

\section{The Second Stage}

The second stage carried out in this research is the validity test. According to Ghozali (2005:51) Test validity test of the data used to measure the validity of a questionnaire. A questionnaire will be valid if the questions on the questionnaire are able to reveal something that will be measured by the questionnaire. This validity test doing by comparing the calculated $\mathrm{R}$ value and $\mathrm{R}$ table. If the calculated $\mathrm{R}$ value $>\mathrm{R}$ table, it

Table 1. Participation Rate Data

\begin{tabular}{|c|c|c|c|c|}
\hline Name of Waste Bank & Number of Members & Number of $\mathrm{KK}$ & Percentage (\%) & Number of Samples \\
\hline Margo Sampah Jaya & 60 & 250 & 24 & 30 \\
\hline Giat Barokah & 60 & 235 & 2.5 & 30 \\
\hline Subur Makmur & 125 & 400 & 31.25 & 30 \\
\hline Ikhlas & 80 & 344 & 23.25 & 30 \\
\hline Pemuda & 55 & 250 & 22 & 30 \\
\hline Kembangsari & 85 & 275 & 30.90 & 30 \\
\hline Oreo & 70 & 350 & 20 & 30 \\
\hline Lestari & 120 & 300 & 40 & 30 \\
\hline Barongan Resik & 60 & 288 & 20.83 & 30 \\
\hline RAS & 110 & 270 & 40 & 30 \\
\hline
\end{tabular}


Table 2. Reability Test Result

\begin{tabular}{lcc}
\hline Variables & Cronbach's Alfa & Conclusion \\
\hline Intention & 0,756 & Reliable \\
Attitude & 0,818 & Reliable \\
Subjective Norm & 0,765 & Reliable \\
Percieved Control & 0,636 & Reliable \\
KOHW & 0,803 & Reliable \\
KOC & 0,875 & Reliable \\
Behavior & 0,799 & Reliable \\
Situational Factor & 0,733 & Reliable \\
\hline
\end{tabular}

Table 3. Validity Test Result

\begin{tabular}{|c|c|c|c|c|c|c|c|c|c|}
\hline No & Indicator & Rresult & Rtable & Conclusion & No & Indicator & Rresult & Rtable & Conclusion \\
\hline \multirow[t]{9}{*}{1} & Intention & & \multirow{9}{*}{0.1241} & & & 2 & 0.595 & \multirow{6}{*}{0.1241} & Valid \\
\hline & 1 & 0.421 & & Valid & & 3 & 0.547 & & Valid \\
\hline & 2 & 0.47 & & Valid & & 4 & 0.699 & & Valid \\
\hline & 3 & 0.603 & & Valid & & 5 & 0.484 & & Valid \\
\hline & 4 & 0.564 & & Valid & & 6 & 0.605 & & Valid \\
\hline & 5 & 0.529 & & Valid & & 7 & 0.395 & & Valid \\
\hline & 6 & 0.555 & & Valid & 6 & $\mathrm{KOC}$ & & \multirow{11}{*}{0.1241} & \\
\hline & 7 & 0.499 & & Valid & & 1 & 0.655 & & Valid \\
\hline & 8 & 0.194 & & Valid & & 2 & 0.698 & & Valid \\
\hline \multirow[t]{8}{*}{2} & Attitude & & \multirow{8}{*}{0.1241} & & & 3 & 0.435 & & Valid \\
\hline & 1 & 0.509 & & Valid & & 4 & 0.614 & & Valid \\
\hline & 2 & 0.48 & & Valid & & 5 & 0.522 & & Valid \\
\hline & 3 & 0.626 & & Valid & & 6 & 0.577 & & Valid \\
\hline & 4 & 0.611 & & Valid & & 7 & 0.611 & & Valid \\
\hline & 5 & 0.55 & & Valid & & 8 & 0.701 & & Valid \\
\hline & 6 & 0.498 & & Valid & & 9 & 0.586 & & Valid \\
\hline & 7 & 0.659 & & & & 10 & 0.62 & & Valid \\
\hline \multirow[t]{10}{*}{3} & Subjective Norm & & \multirow{10}{*}{0.1241} & & 7 & Behavior & & \multirow{10}{*}{0.1241} & \\
\hline & 1 & 0.437 & & Valid & & 1 & 0.35 & & Valid \\
\hline & 2 & 0.464 & & Valid & & 2 & 0.615 & & Valid \\
\hline & 3 & 0.502 & & Valid & & 3 & 0.443 & & Valid \\
\hline & 4 & 0.545 & & Valid & & 4 & 0.514 & & Valid \\
\hline & 5 & 0.467 & & Valid & & 5 & 0.532 & & Valid \\
\hline & 6 & 0.488 & & Valid & & 6 & 0.598 & & Valid \\
\hline & 7 & 0.38 & & Valid & & 7 & 0.431 & & Valid \\
\hline & 8 & 0.445 & & Valid & & 8 & 0.408 & & Valid \\
\hline & 9 & 0.31 & & Valid & & 9 & 0.598 & & Valid \\
\hline \multirow[t]{6}{*}{4} & Perceived Control & & \multirow{6}{*}{0.1241} & & 8 & Situational & & \multirow{7}{*}{0.1241} & \\
\hline & 1 & 0.275 & & Valid & & 1 & 0.35 & & Valid \\
\hline & 2 & 0.452 & & Valid & & 2 & 0.537 & & Valid \\
\hline & 3 & 0.459 & & Valid & & 3 & 0.531 & & Valid \\
\hline & 4 & 0.403 & & Valid & & 4 & 0.53 & & Valid \\
\hline & 5 & 0.387 & & Valid & & 5 & 0.328 & & Valid \\
\hline \multirow[t]{2}{*}{5} & KOHW & & & & & 6 & 0.26 & & Valid \\
\hline & 1 & 0.554 & & Valid & & & & & \\
\hline
\end{tabular}

mean that the measuring instrument used is valid, but if the calculated $\mathrm{R}$ value is $<\mathrm{R}$ table, it mean that the measuring instrument used is invalid or invalid. The questionnaire in this study consisted of 61 items. After testing the validity of the 61 question items, all question items on each variable resulted in the calculated value of the correlation coefficient $\mathrm{R}$ value greater than the $\mathrm{R}$ table so it can be concluded that the statements contained in the questionnaire are valid as shown on Table 3.

\section{The Third Stage}

The third stage in this research is the classical assumption test which consists of normality test, heteroscedasticity test and multicollinearity test. The normality test in this study showed that sig. $>0.05$ (0.341 $>0.05$ ) as shown on Figure 3, so it can be concluded that the data is normally distributed. Furthermore, the heteroscedasticity test shows no heteroscedasticity symptoms because the residue points randomly spread over and below the diagonal line. This is reinforced by 


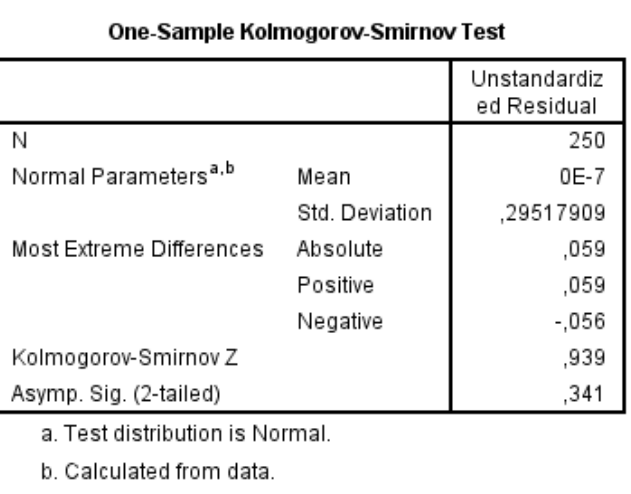

Figure 3. Result of Normality Test Factor

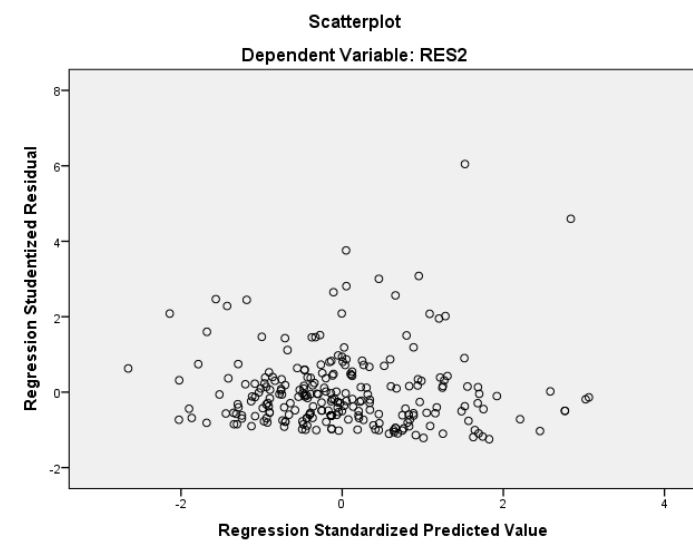

Figure 4. Heteroscedasticity Test Scatterplot

Table 4. Tolerance and VIF Values

\begin{tabular}{lcc}
\hline \multirow{2}{*}{ Variables } & \multicolumn{2}{c}{ Collinearity Statistics } \\
\cline { 2 - 3 } & Tolerance & VIF \\
\hline Attitude & 0,572 & 1,749 \\
Subjective Norm & 0,707 & 1,415 \\
Percieved Control & 0,710 & 1,409 \\
KOHW & 0,503 & 1,990 \\
KOC & 0,493 & 2,028 \\
Situational Factor & 0,650 & 1,539 \\
\hline
\end{tabular}

Table 5. Hypothesis Analysis Results

\begin{tabular}{|c|c|c|c|c|}
\hline Hypothesis & $B$ & t-value & Sig. & Conclusion \\
\hline $\begin{array}{l}\mathrm{H}_{1}: \text { Attitude has a significant effect on people's } \\
\text { intentions to participate in the waste bank } \\
\text { programs }\end{array}$ & .373 & 8.286 & .000 & Significant \\
\hline $\begin{array}{l}\mathrm{H}_{2}: \text { Subjective norm has a significant effect on the } \\
\text { people's intention to participate in the waste bank } \\
\text { programs }\end{array}$ & .040 & 1.986 & .048 & Significant \\
\hline $\begin{array}{l}\mathrm{H}_{3} \text { : Perception control has no significant effect on the } \\
\text { people's intention to participate in the waste bank } \\
\text { programs }\end{array}$ & .014 & .550 & .583 & $\begin{array}{c}\text { Not } \\
\text { Significant }\end{array}$ \\
\hline $\begin{array}{l}\mathrm{H}_{4}: \text { Knowladge how and why has a significant effect on } \\
\text { the people's intention to participate in the waste } \\
\text { bank programs }\end{array}$ & .173 & 4.440 & .000 & Significant \\
\hline $\begin{array}{l}\mathrm{H}_{5} \text { : Knowladge of consequences has a significant effect } \\
\text { on the people's intention to participate in the waste } \\
\text { bank programs }\end{array}$ & .189 & 4.073 & .000 & Significant \\
\hline $\begin{array}{l}\mathrm{H}_{6} \text { : Situasional Factor has a significant effect on the } \\
\text { people's intention to participate in the waste bank } \\
\text { programs }\end{array}$ & -.100 & -2.737 & .006 & Significant \\
\hline $\begin{array}{l}\mathrm{H}_{7} \text { : Intention' has a significant effect on the } \\
\text { people's behavior to participate in the waste } \\
\text { bank programs }\end{array}$ & 1.231 & 14.320 & .000 & Significant \\
\hline
\end{tabular}

the sig results $>0.05$ which means that there is no heteroscedasticity as shown on Figure 4. The last assumption test is the multicollinearity test, based on the results of data processing, it shows that the tolerance value $\geq 0.10$ or VIF value $\leq 10$, which means that there is no multicollinearity in the data as shown on Table 4.

\section{The Fourth Stage}

The fourth stage in this research is the multiple regression analysis test or the analysis of the results of the hypothesis. Based on the results of multiple linear regression analysis, it is show that there are 5 independent variables that have a significant effect on the dependent variable and there is 1 independent variable that has no significant effect on the dependent variable. The results of the hypothesis analysis, both stage (1) measuring the intention of respondents in following the waste bank activities and stage (2) measuring the respondent's behavior in participating in waste bank activities are shown in Table 5. 


\subsection{Discussion}

Basic thinking for this research is to observe the determinant factors of the intention to participate in the waste bank activities, namely attitudes, subjective norms, perceptual control, knowledge of what and why, knowledge of consequences and situational. The results of this research indicate that the variables of attitudes, subjective norms, knowledge of how and what, knowledge of consequence, and situational have a significant effect on the intention variable, this supports the initial hypothesis of the study ( $\mathrm{H} 1, \mathrm{H} 2, \mathrm{H} 4, \mathrm{H} 5, \mathrm{H} 6)$. Then this research also supports the theory which states that the intention which has been influenced by the independent variable has a significant effect on the behavior variable (H7). This can be seen from the sig < 0.05 , which means that the independent variable has a significant effect on the dependent variable). However, this research does not support the hypothesis which states that the perception control variable has a significant effect on the intention variable $(\mathrm{H} 3)$, the results of this study state that the perception control variable is not significant in influencing the variable. Perceptual control in this study is defined as how far a person feels confident or able to do something (Endah, 2014).

The results of the regression carried out in the first model 1 , namely multiple regression, get an $\mathrm{R}$ square (R2) value of 0.447 , this means $44.7 \%$ Attitude, subjective norm, perception control, knowledge of how and what, knowledge of consequences, and situational can explain participation intention of the people, while the remaining $52.6 \%$ is explained by causes outside of the model. The relationship of each variable shows that the independent variables of attitude, subjective norm, knowledge of how and what, knowledge of consequences and situational have a positive relationship to the intention variable. Then intention also has a positive relationship to the behavior variables. This can be seen from result $B$ which shows a positive number so that it is concluded that all independent variables have a positive relationship with the dependent variable.

This study also adds factors outside the conceptual model of Theory Planned of Behavior, namely knowledge how and what factors, knowledge of consequence and situational factor. According to Young, 1989 (as cited in Pratiwi, (2018) Knowledge of how and what is an understanding of how to recycle waste and what kind of waste will be recycled with the aim of being able to separate the types of waste that exist. According to Park et al. (2014) Consequence knowledge represents the person's tendency to link their own behavior with the welfare of others. Situational factors in this study are defined as external factors that contribute to influencing peoples to participate in an activity, situational factor made an easy access for peoples to do something/ activities, situational factors include government facilities and policies.

The results of data said that knowledge how and what, knowledge of consequence, and situational factor have a significant effect on a person's intention to participate in waste bank activities. This is supported by the results of previous studies, like the research of Gadiraju, (2016); Tonglet, (2004); Young 1989 (as cited in Pratiwi, (2018); Prihatmoko, (2018) said that the factors of knowledge how and what, knowledge of the consequences are significant in influencing someone to participate in recycling activities. Besides research Davis et al (2002); Latif (2012) ); Ittiravivong (2011); Pratiwi (2018) showed that situational factors significantly affect the intention of community participation in doing recycling activities.

\section{Conclusion}

This study aims to determine the effect and relationship of attitude variables, subjective norms of perceived control, knowledge how and what, knowledge of consequence, and situational on people's intention to participate in waste bank activities. And, to see the influence and relationship of the intention variable (intention that has been influenced by the independent variable) to the person's behavior variable in participating in the waste bank activities. The result of this research indicates that attitudes, subjective norms, knowledge how and what, knowledge of consequences, and situational factor have a positive and significant influence on a people's intention to participate in waste bank activities. Then the intention' (intention that has been influenced by the independent variable) also has a positive and significant effect on a person's behavior in participating in waste bank activities. However, this study shows that the perceived control variable has an insignificant influence in influencing the intention variable All of these factors can simultaneously explain the intention of $44.7 \%$. The implication of this research for waste bank activity managers or administrators can find out what factors make people more active in participating in waste bank activities, so that they can increase the activities of the waste bank, such as holding socialization about the importance of recycling waste, participating in waste bank activities, providing knowledge about the types and ways to recycle waste regularly every week. Improve the facilities of the waste bank program, such as a large space for recycling waste, tools for recycling, the number of waste banks, permanent waste bank buildings, ease of participating in waste bank activities. This is mainly for the environment. Future research should be considered additional variables besides the variables in this study such as norms, experience, motivation, and income together with TPB variables and investigate more specific population variations. Recycling habits may be different for different races. Future research should analyze recycling habits by race to understand how recycling intentions by race. And future research should try to investigate the community's intention to recycle both in Bantul Regency and outside Bantul Regency because recycling habits may be different by location. Using new conceptual model, the future research could place emphasis on the different contexts in which surveys can be conducted. For example, a questionnaire can be distributed not only to people who actively participate in waste bank activities 
but to all members of the waste bank, both active and inactive so they will obtain input data from various perceptions. Instead of focusing on recycling in general, the focus should be placed on certain recycled materials. For example, focus research on paper or plastic-based recycling rather than asking about recycling behavior in general. Based on the limited time and resources, a survey technique was used for this research.

\section{Reference}

Ajzen, I. (1991). The Theory of Planned Behavior. Organizational Behavior and Human Decision Processes, 50(2), 179-211.

Boldero, J. (1995). The Prediction of Household Recycling of Newspapers: The Role of Attitudes, Intentions, and Situational Factors. Journal of Applied Social Psychology, 25 (5), 440 - 462.

Batriyana, H. (2007). The Scope of Waste and Its Problems. Makassar: Indonesian Muslim University.

Davies, J., GR, F., and Pallister, J. (2002). Beyond the Intention-Behavior Mythology: An Integrated Model of Recycling. Market Theory, 2 (1), 29-11.

Gusti, B. I. (2015). Determinant Factors of Sustainable Waste Management Behavior Intention in Elementary School Students. Andalas Public Health Journal, 9 (2), 65-72.

Gadiraju, T. (2016). Investigating The Determinants of Recycling Behavior in Youth By Using Theory of Planned Behavior. Thesis. University of South Florida, United States.

Hair, J. F., Black, W. C., Babin, B. J., \& Anderson, R.E. (2017). Multivariate Data Analysis. New York: Pearson Higher Ed.

Ittiravivongs, A. (2011). Factors Influence Household Solid Waste Recycling Behavior in Thailand: An Integrated Perspective. WIT Transactions on Ecology and The Environment, 167, 437 - 448.

Irsyandi, A. (2012, August). Population Data Kab. Bantul. Bantulkab.bps.go.id: Https://bantulkab.bps.go.id accessed on March Tuesday, 2021.

Khurniawan, M. A., Harida, A., and Maarif, A. F. (2017). Analysis of The Influence of Community Intention and Behavior in a Waste Bank Using the Theory of Plan Behavior Model (Case Study in West Bantul District). Thesis. Yogyakarta: Ahmad Dahlan University.

Latif, S. A., Omar, M.S., Bidin, Y.S., and Awang, Z. (2012). Environmental Problems And Quality of Life: Situational Factor As A Predictor of Recycling Behavior. Procedia - Social and Behavioral Sciences, 35, 682 - 688 .

Mulansari, M. (2014). A Complete Guide to Recycling Waste. Malang: State University of Malang.

Nuswantoro (2019, April). Regional Technical Implementation Unit for Cleanliness, Garbage, and Landscaping, Bantul Regency. Regulation. bpk.go.id:https://peraturan.bpk.go.id/home/
Details/ 92279/ Perbup-Kab-Bantul accessed on March Monday 2021.

Prastiyantoro, W. (2017). Community Participation in Participating in Waste Bank Activities. Thesis. Tadulako University, Central Sulawesi.

Prayugo, D. (2017, February). Bantul Regency Environmental Service. dlh.bantulkab.go.id: http://dlh.bantulkab.go.id accessed on March Tuesday, 2021.

Pratiwi, W. M. (2018). Analysis of Public Participation Intention in Waste Bank Activities Using Factors in the TPB Model and Situational Factors. Thesis. Yogyakarta: Ahmad Dahlan University.

Prihatmoko, B. S. (2018). Analysis of the Influence of Community Intention and Behavior in a Waste Bank Using the Theory of Plan Behavior Model (Case Study in Pundong and Jetis Districts). Thesis. Yogyakarta: Ahmad Dahlan University.

Ramayah, T., Tan, C. H., Yeap, J. A., and Ooi, S. K. (2017). Examining Residents' Receptiveness Towards E-Waste Recycling in Penang, Malaysia. Global Business and Management Research: An International Journal, 9(4), 374 - 390.

Singhirunnusorn, W., Donlakorn, K., and Kaewhanin, W. (2012). Contextual Factors Influencing Household Recycling Behaviors: A Case of Waste Bank Project In Mahasarakham Municipality. Procedia - Social and Behavioral Sciences, 36 , 688-697.

Sulistiorini, I. N. (2012, February). Department of Environment and Forestry DIY. dlhk.jogjaprov.go.id:

https://dlhk.jogjaprov.go.id/peng Manajemensampah- households accessed on March Monday, 2021.

Sugiyono, A. (2012). Sampling Technique in Research Methods. Makassar: Hasanuddin University.

Sun, S. W. (2018). Analysis of Community Participation Intentions in Waste Bank Activities in the City of Yogyakarta Based on Intention Factors in The Theory of Planned Behavior and Situational Factors. Thesis. Yogyakarta: Ahmad Dahlan University.

Tonglet, M., Phillips, P. S., and Read, A. D. (2004). Using The Theory of Planned Behavior To Investigate The Determinants of Recycling Behavior: A Case Study From Brixworth, UK. Resources, Conservation and Recycling, 41, 191 $-214$.

Taqwarahman, R. G. (2018). Analysis of the Influence of Community Intentions and Behavior in Waste Bank Activities Using Modified Theory of Planned Behavior Model. Thesis. Yogyakarta: Ahmad Dahlan University.

Vassanadenumrongdee, S. and Kittipongvises, S. (2017). Factors Influencing The Intention of Subsistence Separation And Willingness to Pay to Improve Waste Management in Bangkok, Thailand. Sustainable Environmental Research, 28, 90 - 99. 